\title{
Review of Syaria Economy Disputes in Religious Courts within the Perspective of Small Claims Court (SCC)
}

\author{
Anita Afriana ${ }^{1}$, Hazar Kusmayanti ${ }^{2}$ \\ ${ }^{1}$ Faculty of Law, Universitas Padjadjaran, Indonesia, E-mail: anita.afriana@ unpad.ac.id \\ ${ }^{2}$ Faculty of Law Universitas Padjadjaran, Indonesia, E-mail: hazar.kusmayanti@unpad.ac.id
}

Submitted: October 12, 2020; Reviewed: November 24, 2020; Accepted: December 14, 2020

\begin{tabular}{l}
\hline \multicolumn{2}{c}{ Article Info } \\
\hline Keywords: \\
Religious Court;, Small Claims \\
Court; Sharia Economy.
\end{tabular}

DOI:

10.25041/fiatjustisia.v15no2.2086
One of the absolute competencies of the Religious Court revolves around resolving sharia economy disputes. Quick, simple and inexpensive principles of the court must persist within Religious Court procedures, such as in sharia economy disputes relating to business disputes as regulated in Supreme Court Decree No. 14 of 2016 on Procedures in Sharia Economic Disputes. The solution in this way should be able to speed up commercial Shia dispute, but in fact, various obstacles were found. This article reviews the resolution of sharia economy disputes in Religious Court within the perspective of Small Claims Court implied through SC Decree No. 14 of 2016, along with the possible issues of Small Claims Court in Religious Court procedures. This research was conducted with a normative approach. Juridically SC Decree No. 14 of 2016 conforms with SC Decree No. 2 of 2015, now replaced with SC Decree No. 4 of 2019, permits parties to resolve certain nominal claims through a quicker dispute settlement procedure. Judges participate actively throughout the dispute resolution as Small Claims Court provides flexible interaction within formal courts. In practice, limitations such as the amount of sharia economy certified judges show that sharia economy cases are better resolved through standard procedure within the Civil Court. Other limitations, such as the insufficient electronic court (ecourt) systems, limit dispute resolution capacity with further substantial limitations such as executorial clauses that are not yet regulated and can take more than 25. 


\section{A. Introduction}

The linguistic definition of court refers to a public, official forum where legal authorities establish public powers to address disputes and seek justice in civil, labor, administrative and criminal matters under rules of law. Parties which feel that their rights have been harmed or seek protection under law, in last resort efforts file claims to court. ${ }^{1}$

The court's role is regulated under Article 24 (1) of the Indonesian Constitution of 1945, which stipulates, "the judicial powers shall be independent with authority to organize the judicature in order to uphold law and justice". Therefore, the judiciary bodies' main purpose is to uphold the law and ensure justice to all of society. In practice, resolving disputes in court implicates court's procedural rules, hence resolving disputes in court is the last resort by parties that have not solved the dispute through alternative procedures such as negotiation, mediation or arbitration.

Dispute resolution in civil courts relies on simple, quick and inexpensive principles. These principles are universal in every court worldwide. In Indonesia, it is reflected in Article 2 (4) and Article 4 (2) of Law No. 48 of 2009 on Judicial Powers.

Such principles, simple, quick and inexpensive, are also applicable in Religious Court. As established under rules of law, Religious Court has the absolute competency to resolve disputes appointed to it. This also implies that there are certain disputes that can only be resolved through religious courts. The Religious Court's competency is established under Article 49 of Law No. 3 of 2006 on changes to Law No. 7 of 1989 on Religious Court which consists of marriage, heir, will, bequest, wakaf, sadaqah, infaq, zakat and sharia economy. (Law No. 50 of 2008 on second change to Religious Court Law).

There are two claims of rights in religious courts: contentious (contentius) cases and declaratory (voluntair) cases. Contentious cases are cases in court that convey a dispute of two or more parties. Declaratory cases are cases which convey a single party requesting a declaratory statement from court. ${ }^{2}$ HIR or $\mathrm{RBg}$ does not differentiate the process of filing for cases.

There are two forms of claims or requests as established by Article 120 HIR or 144(1) of RBg, written and unwritten or verbal. Furthermore, Article 145 and Article 718 Rbg, Article 121 and Article 390 HIR elaborate that there must be an official call to court. The elaboration on the process and requirements in filing for Religious Court clearly establishes that there is no difference in filing for contentious and declaratory cases by law. Procedural

\footnotetext{
${ }^{1}$ Hazar Kusmayanti, Sherly Ayuna Putri, Linda Rahmainy, "Praktik Penyelesaian Sengketa di Pengadilan Agama Melalui Sidang Keliling Dikaitkan dengan Prinsip dan Asas Hukum Acara Perdata", JHAPER 4, no. 2 (2018): 145-161, 146, DOI: 10.36913/jhaper.v4i2.83.

2 Yahya Harahap, Kedudukan Kewenangan Dan Acara Peradilan Agama Berdasarkan Undang-Undang No. 7 Tahun 1989 (Jakarta: Sinar Grafika, 2003), 198.
} 
law in Religious Court does not differentiate both processes. There is no classification in resolving disputes that affect the simple, quick and inexpensive principles of court as reflected in case matters of varying degrees of difficulty in Religious Court. The 2018 Yearly report publishes by the Supreme Court states that religious courts handled 630.049 cases, consisting of 528.514 claims and 101.535 requests. From this total, 549.217 cases are resolved, with 72.600 remaining cases. ${ }^{3}$ Data shows that several cases remain unresolved until 2019. Meanwhile in theory, the court has applied quick, simple and inexpensive principles. ${ }^{4}$

Considering the examination process in court, it is often found that quick, simple, and inexpensive principles are inapplicable in procedural law. Even though these principles are clearly established under Indonesian laws. As a consequence, parties are reluctant to rely on courts to enact their rights as in practice, the resolution is complex, time-consuming and expensive. ${ }^{5}$

A simple, quick and inexpensive court system is a necessity in the legal dynamic in Indonesia. In resolving civil disputes, through SC Decree No. 2 of 2015 on Procedures on Small Claims Resolution (hereinafter SC Decree No. 2 of 2015). Based on the effectiveness and efficiency of the small claims mechanism in resolving disputes with a certain nominal limit in claims, a nominal of up to IDR 200.000.000 (Two Million Rupiah) was set to limit the accessibility of parties claiming under the mechanism. SC Decree No. 4 of 2016 was then promulgated with several changes in regards to the nominal of claims. In small claims, parties in filing claims to court submit evidence including nezegeling of original documents. The court secretariat will then classify if the filed case can be resolved through the small claims mechanism, the single judge assigned to the case can therefore reject to proceed if the filing does not fulfil the requirements of small claims. ${ }^{6}$

The term of Small Claims Court (SCC) is persistent both in common and civil law countries. One of the main objectives is to provide access to justice further, considering that the court's procedure that parties must comply to overshadows the nominal of claims that is relatively small. The regulatory

\footnotetext{
${ }^{3}$ Supreme Court Report 2019.

${ }^{4}$ Muharrom Ainul Yaqin, "Konsep Small Claim Procedure Untuk Menyelesaikan Perkara Perdata Permohonan (Volunter) Di Pengadilan Agama”, Jurisdictie 6, no. 1 (2015): 37-48, 38, DOI: 10.18860/j.v6i1.4088, as cited by Erfaniah Zuhriah, "Model SCC Sebagai Alternatif Penyelesaian Perkara di Pengadilan Agama Perspektif Teori Keadilan John Rawls", De Jure: Journal of Law and Syar'iah 11, no. 2 (2019): 128-142, 129, DOI: 10.18860/j-fsh.v11i2.6580. ${ }^{5}$ Hazar Kusmayanti, et.al, "Sidang Keliling dan Prinsip-prinsip Hukum Acara Perdata: Studi Pengamatan Sidang Keliling di Pengadilan Agama Tasikmalaya", JHAPER 1, no. 2 (2015): 101-116, 101, DOI: 10.36913/jhaper.v1i2.14.

${ }^{6}$ Anita Afriana, "Dasar Filosofis Dan Inklusivitas Gugatan Sederhana Dalam Sistem Peradilan Perdata", Ubelaj 3, no. 1 (2018): 1-14,8, DOI: 10.33369/ubelaj.3.1.1-14
} 
mechanism of SCC is to guarantee the infrastructure of civil court resolution includes the simple, quick and inexpensive principles in small nominal cases. ${ }^{7}$

First introduced in Australia, SCC was quickly accepted into other common law countries such as the USA and Singapore. The SCC model of dispute settlement implicates a single judge, no jury and a simplified examination. SCC Procedure in SC Decree No. 2 of 2015 differentiates several procedures established under $\mathrm{HIR} / \mathrm{RBg}$ the bases of civil procedural law. ${ }^{8}$

Phillip Sebastian Angermayer, in his article, portrays small claims court as a public service that can be used by society. Unlike a more formal court, where the interaction of the judge is mediated and translated by an attorney, many parties involved in SCC are inexperienced in legal dispute resolution and can request procedural or substantial aid from the courthouse. At the same time, as the number of claims was much less, the amount of individual cases is insignificant to the total cases in the New York judiciary system, with only a small specification for SCC. ${ }^{9}$

The SCC mechanism was mainly purposed to be used in the field of general civil courts, nevertheless the Religion Court system which competences in the field of sharia economy was also in need of a SCC system. The mechanism was then introduced through SC Decree No. 14 of 2016 on Sharia Economy Dispute Settlement Procedure (Hereinafter SC Decree No. 14 of 2016). The urgency of SC Decree No 14 of 2016 was namely to further perfect the legal system in face of the growing sharia economy activities in society.

Sharia Economy Disputes are disputes between one or more parties in economy matters, where such matters arise under applicable sharia and economy law. Understanding the correlation of law and individuals in the economy field, specifically in the area of agreements using sharia principles which have grown rapidly, and growth of the sharia economy market in Indonesia in financial, banking and more fields of economy, the potential of sharia economy disputes arises, hence arising the need for a solid legal platform to ensure justice. In consideration of this fact, a mechanism is needed which is simple, quick and inexpensive, specifically in everyday legal transactions. ${ }^{10}$

\footnotetext{
${ }^{7}$ Mul Irawan, et.al, Small Claim Court dan Pengadilan Agama Sebuah Catatan Pembuka (Jakarta: Puslitbang Hukum dan Peradilan Mahkamah Agung, 2018), 3.

8 Anita Afriana, Isis Ikhwansyah, "Questioning the Small-Claims Court in Indonesia in the Framework of National Civil Procedural Law Reform", Jurnal Dinamika Hukum 16, no. 3 (2016): 266-272, 267, DOI: 10.20884/1.jdh.2016.16.3.580.

${ }^{9}$ Philipp Sebastian Angermeyer, "Monolingual Ideologies and Multilingual Practices in Small Claims Court: the Case of Spanish-Speaking Arbitrators", International Journal of Multilingualism, International Journal of Multilingualism 11, no. 4 (2014): 430-448, 431, DOI: 10.1080/14790718.2014.944531.

${ }^{10}$ Erfaniah Zuhriah, Loc.Cit.
} 
As these disputes arise from sharia law, the settlement should also be under the basis of sharia law. As lately transaction arising from sharia law also involves financial parties such as banks, the potential of a filing into Religious Court becomes very likely. Thus, it becomes the focus to review how SC Decree No. 14 of 2016 is applied in Religious Court, what issues arise through the application, and how it affects the justice system.

The approach this research applies is normative legal methodology. The normative legal approach is a research methodology that finds the logical legal substance through a normative perspective. ${ }^{11}$ Research through this legal perspective focuses on the normative substance of civil procedural law norms and comparison of law through principles of laws that benchmark as appropriate. The specification of research used is descriptive and analytical in nature, through the production of data or description as accurately as possible to the problem. ${ }^{12}$

\section{B. Discussion}

\section{Sharia Economy Dispute Resolution from Small Claims Court Perspective}

Pursuant to Article 49 (I) of Law No. 3 of 2006 jo. Law No. 50 of 2009 on Religious Court, sharia economy is an action or business activities carried out according to sharia principles, including sharia banking. Hence from the definition provided by the article, sharia banking is a matter within the field of sharia economy under the competency of the Religious Court. The promulgation of Law No. 21 of 2008 further establishes the mechanism of dispute settlement between banks and their users, the procedure in the dispute settlement of sharia banking is encompassed in Article 55 (1), (2) and (3). ${ }^{13}$

Research shows that sharia economy dispute settlements between 2006 until 2016 rely on civil procedural law. The use of civil procedural law in sharia economy dispute settlement is consistent with Article 54 of Law no 7 of 1989 jo Law No. 3 of 2006 on changes to Law No. 7 of 1989 on Religious Court, which states that "procedural laws applicable in religious court is the law applicable to the general court, unless stipulated otherwise under this law". ${ }^{14}$

\footnotetext{
11 Johnny Ibrahim, Teori dan Metodologi Penelitian Hukum Normatif (Malang: Bayumedia, 2013), 57.

${ }^{12}$ Soerjono Soekanto and Sri Mamudji, Penelitian Hukum Normatif, Suatu Tinjauan Singkat (Jakarta: Radja Grafindo Persada, 2012), 19.

${ }^{13}$ Dhian Indah Astanti, et.al. "Kewenangan Pengadilan Agama Dalam Penyelesaian Sengketa Perbankan Syari'ah", Jhaper 5, no. 1 (2019): 167-180, 170, DOI: 10.36913/jhaper.v5i1.

14 Sinta Noer Hudawati, "Problematika Hukum Formil Penyelesaian Sengketa Ekonomi Syari'ah Di Pengadilan Agama”, Jurnal Penegakan Hukum dan Keadilan 1, no.1 (2020): 1740, 70, DOI: 10.18196/jphk.1102.
} 
The development of the sharia economy system in Indonesia is increasingly rapid. A key indicator is the growth of new sharia banks in Indonesia. The indication of sharia banks in Indonesia is further highlighted through government regulations encompassing sharia banking. ${ }^{15}$

In practice, dispute settlement through litigation (court) is considered ineffective and limits business activities. This is caused by the court procedure, which is slow and time-consuming as a consequence of the examination system that is very formal and technical; expensive case costs (filing a suit cost Rp. 500.000 - Rp. 750.000, attorney costs, seizure costs, witness investigation costs, and other expenses during the procedure); courts that are not viewed as objective towards justice along with decisions which do not solve but further raise issues as one party wins and another loses. ${ }^{16}$

The ineffective litigation process does not accommodate businessrelated dispute settlements such as disputes of lower value material clams. To overcome the issue, on the $22^{\text {nd }}$ of December 2016, the Supreme Court of Indonesia promulgated SC Decree No. 14 of 2016 on Sharia Economy Dispute Settlement Procedures. In the SC Decree, sharia economy disputes can be resolved under two procedural rules, normal procedures and simple procedures.

In matters of the Public Court, since SC Decree No. 2 of 2015 on Procedures of Small Claims, although in small numbers, the application of small claims has shown effectiveness. With the small claim procedure, the public court relatively accomplished applying the principles of effective and efficient procedures while also reducing the number of civil cases, namely in higher courts. The small claims mechanism is different from regular claims as the nominal of the claims are much less, parties involved and legal domicile adhered to SCC rules. ${ }^{17}$ Meanwhile, the enforcement of the SCC settlement procedure at the Religious Courts through SC Decree no. 14 of 2016 is related to the formal aspects (procedural law) of shariah economy law enforcement which is the absolute competency of Religious Courts. In fact, it has given stronger authority to the Religious Court in examining and adjudicating shariah economy disputes. Until now, this competency has not been supported by adequate procedural law. ${ }^{18}$

\footnotetext{
15 Ikhsan Al Hakim, "Penyelesaian Sengketa Ekonomi Syari'ah di Pengadilan Agama", Pandecta 9, no. 2 (2014): 269-287, 270, DOI: 10.15294/pandecta.v9i2.3580.

${ }^{16}$ Efa Laela Fakhriah, "Mekanisme Small Claims Court Dalam Mewujudkan Tercapainya Peradilan Sederhana, Cepat, dan Biaya Ringan”, Mimbar Hukum 25, no. 2 (2013): 258-270, 260, DOI: $10.22146 /$ jmh. 16096 .

${ }^{17}$ Supreme Court Report 2016.

18 Arifin, "Kerangka Hukum Penyelesaian Gugatan Sederhana Dalam Sengketa Ekonomi Syari'ah, This paper delivered in IKAHI Law Discussion, PTA Bandar Lampung Region 2018, on January 12, 2018, in Bukit Randu Hotel, Bandar Lampung.
} 
SC Decree No. 2 of 2015 as amended by SC Decree No. 4 of 2019 and SC Decree No. 14 of 2015 is part of an effort to fill the legal void that HIR / $\mathrm{RBg}$ has never touched, HIR / RBg does not differentiate civil dispute settlement procedures based on the material value of the lawsuit, even though this distinction is very important and responsive to the public needs. The existence of a simpler, faster and less costly dispute settlement procedure, especially in civil law proceedings;

Through the elaboration above, the authors see the benefits of SCC being applied to the Religious Courts, namely:

a. SC Decree No. 14 of 2016 accelerates the settlement of sharia cases with light claims. Thus legal certainty and justice for the parties can be achieved.

b. SCC within SC Decree No. 14 of 2016 is considered very accommodating to information technology development. Apart from legitimizing online case registration, Article 11 of SC Decree No. 14 of 2016 provides expert examination opportunities through information technology such as teleconferences. If the parties agree, the procedure can take advantage of information technology, such as simply by using e-mail or Whatsapp.

c. Sc Decree No. 14 of 2016 is the first regulation accommodating the possibility of filing cases online to the Religious Court.

d. Acceptance and settlement of cases are quicker as it includes a simple lawsuit format, components and amount of court fee down payment, case registers, format of determination by a single judge regarding the feasibility of a small claims case, the format of trial minutes and decisions, as well as procedures and costs of legal remedies. Regarding the lawsuit form, some courts have provided it, and some have not. Usually, lawsuits can be found in various formats, following the types of cases that are the Religious Court's absolute competence as no regulation regulates it. Therefore, the implementation of SCC in sharia economy disputes needs a more specific regulation.

Based on the description above, SC Decree No. 14 of 2016 has also regulated the SCC mechanism together with electronic case filing or what is known as an e-court, providing easy access for parties so that dispute settlement is faster. The existence of SC Decree No. 14 of 2016 is a progressive step by the Supreme Court in implementing the principles of quick, simple, and inexpensive in sharia economy dispute resolution, which in principle is a business dispute that must be resolved quickly and simply.

\section{Issues in implementing Small Claims Court (SCC) in Religious Court}

Today, sharia is developing as the basis for several business activities, as example, banks with sharia principles, insurance, and other non-bank financial institutions. The proliferation of sharia-based business activities often creates conflicts that occur between parties, for example, between debtors and 
creditors or between one business actor and another. Through Article 49 (i) of Law No. 3 of 2006 on changes to Law No. 7 of 1989 on Religious Court, resolving sharia economy disputes is the competency of Religious Court. Even though the elucidation of Article 55 (2) (d) Law No. 21 of 2008 on Sharia Banking provides options for sharia economy dispute resolution through Public Courts. Still, in various meetings with Bank Indonesia, BI has requested sharia banks to include in the contract so that the settlement of sharia economy disputes at the Religious Court.

As part of an economy/business dispute, procedure duration and simplicity are the main keys in dispute resolution. The advantages of settlement through non-litigation institutions (outside court) that many business people choose have advantages in terms of time, confidentiality, and simplicity of mechanisms. However, it does not have legal certainty because non-litigation institutions do not provide executorial powers. Thus, the mediation or consolidation decision and an arbitral award must be implemented by the parties with full awareness and good faith.

The presence of the SCC in Indonesia for the first time in 2015 as a renewal of the proceeding mechanism on the philosophical basis of access to justice, which means that disputing parties with a small claim value, it is not fair to undergo a series of tiring proceedings - starting from filing a claim to ending with a decision. Factually, SCC is intended to accommodate the settlement of business disputes and consumer disputes considering that the nominal value of the claims originally filed is a maximum of Rp. 200,000,000 (Two Hundred Million).

The application of an SCC in the Religious Courts is only intended for the settlement of sharia economy disputes, with the assumption that sharia economy disputes are specific business disputes. An article states that unless specified otherwise, SC Decree No. 14 of 2016 is a lex specialis of MA Decree No. 2 of 2015, legi generalist. Several examples of lex specialis clauses from SC Decree No. 14 of 2016:

Article 3 paragraph (2)

"Claims in sharia economy cases can be filed orally or in writing in printed form or electronic case registration"

\section{Article 4:}

"Plaintiffs file their claims at the court clerkship or through electronic registration or can register their claim by filling out the complaint form provided at the secretariat. The claim form contains information regarding: a. the identity of the plaintiff and defendant; b. brief explanation of the situation of the case; c. the plaintiff's claims; and d. must attach proof of document that has been legalized when registering a small-claims suit." 
The description above shows that there are only 2 provisions that are specifically regulated in SC Decree No. 14 of 2016 and overrules SC Decree No. 2 of 2015. In addition to being resolved conventionally, SCC for sharia economy disputes can also be resolved electronically (e-court). This progress shows that in fact, the Religious Courts, in this case, are more progressive considering that the e-court arrangement was only regulated in 2018 and $e$ litigation in 2019. Furthermore, with the revocation of SC Decree No. 2 of 2015 and the current implementation of SC Decree No. 4 of 2019, the maximum size/value of claims in sharia economy disputes must also be further reviewed.

Based on the results of research conducted by the author at the Sumedang Religious Court and the Bandung Religious Court, even though extensive socialization has been carried out, among others, on the website of the Religious Court, there are several obstacles in resolving sharia economy disputes, among others, relating to:

a. Human Resources (Judge)

Judges who examine and resolve sharia economy disputes must comply with the provisions stipulated in the Supreme Court Regulation No. 5 of 2016 concerning Certification of Sharia Economy Judges. Unlike the settlement of small claims in the District Court with a single judge, small claims in the Religious Court is resolved by a panel of 3 judges;

b. The e-court is not yet maximally optimized in settling sharia economy disputes with SCC.

Whereas the geographical location within Indonesia is very wide and spread throughout the archipelago, the application of e-court is very appropriate because the use of the e-court is very helpful for both courts and the justice-seeking community, applying the principles of quick, simple and inexpensive. However, even though e-court is a futuristic electronic case registration system, it has not been fully implemented in several State and Religious Courts in Indonesia due to obstacles faced in its implementation such as the absence of a standard operating procedures (SOP) and operational/technical guidelines or service standards for electronic services.

c. Execution

The execution of an SCC has not been running as it should be. This is a problem faced by parties who file small claims at the Religious Court and in District Court. The biggest obstacle is the absence of regulations regarding the procedure for the execution of an SCC suit, which is the main basis for the competent authorities (in this case, namely the District Court and the Directorate General of State Assets) in carrying out the execution. The existence of these laws and regulations is an important 
factor to determine the success of implementing an SCC mechanism to realize a quick, simple and inexpensive trial. ${ }^{19}$

So, the analysis below concluded that some problem arises to implementing the SCC to resolve sharia economy dispute. The Supreme Court Regulation No. 14 of 2016 is still far from meeting the expectations of disputing parties who are bound by the sharia contract and seeking a sharia/kaffah complaint settlement because some factors therein are still in compliance with sharia principles. ${ }^{20}$ Apart from some of the obstacles mentioned above, in consideration of SC Decree No. 14 of 2016 referring to SC Decree No. 2 of 2015, the substance in the regulation also provides an opportunity for obstacles to occur in implementation, including those related to: ${ }^{21}$

a. Absolute conditions, such as the domicile of the parties which must be in the same legal domicile hence accessibility is limited;

b. Cases that have not been resolved for more than 25 days;

c. Case value that is very limited, namely at 200 million;

d. Execution is not specifically regulated, thus referring to the usual execution rules and procedures.

\section{Conclusion}

In formal juridical terms, SC Decree No. 14 of 2016 consists of special provisions to SC Decree No. 2 of 2015 as amended by SC Decree No. 4 of 2019 to resolve sharia economy disputes, one of which can be pursued by filing a small-claim suit. With a simple procedural mechanism, it is hoped that it can accelerate the settlement of sharia cases so that legal certainty and justice for the parties can be achieved. Although several Religious Courts have socialized the SCC on their respective court websites, sharia economy disputes are rarely filed through the SCC mechanism. Some obstacles arise in the implementation, among others, related to the judiciary personnel's readiness, such as the limited number of judges who have a sharia economy certification who are not yet fully prepared to examine sharia economy disputes submitted to them either through small-claim suits or ordinary lawsuits. Another obstacle is related to the inadequate electronic service (ecourt), which is intended to speed up the settlement of cases and other substance factors such as execution problems that have not been specifically regulated, causing the implementation to exceed 25 days.

\footnotetext{
19 Anita Afriana and An An Chandrawulan, "Menakar Penyelesaian Gugatan Sederhana, di Indonesia", Jurnal Bina Mulia Hukum 4, no. 1 (2019): 53-71, 68, DOI: 10.23920/jbmh.v4n1.4. ${ }^{20}$ Fiska Silvia Raden Roro, et.al, "The Characteristics of Sharia Compliance in the Settelment of Sharia Economic Disputes in Indonesia", Advance in Sosial Science Education and Humanities Research (ASSEHR) 131, (2017): 113-126, 123, DOI: 10.2991/iclgg-17.2018.15. ${ }^{21}$ Ibid.
} 


\section{References}

Afriana, Anita. "Dasar Filosofis dan Inklusivitas Gugatan Sederhana Dalam Sistem Peradilan Perdata", Ubelaj 3, no. 1, 2018: 1-14, DOI: 10.33369/ubelaj.3.1.1-14.

Afriana, Anita., Chandrawulan, An-An. "Menakar Penyelesaian Gugatan Sederhana, di Indonesia", Jurnal Bina Mulia Hukum 4, no. 1, 2019: 5371, DOI: $10.23920 / \mathrm{jbmh.v4n1.4.}$

Afriana, Anita., Ikhwansyah, Isis. "Questioning the Small-Claims Court in Indonesia in the Framework of National Civil Procedural Law Reform", Jurnal Dinamika Hukum 16, no. 3, 2016: 266-272, DOI: 10.20884/1.jdh.2016.16.3.580.

Al Hakim, Ikhsan. "Penyelesaian Sengketa Ekonomi Syari' ah di Pengadilan Agama", Pandecta 9, no. 2, 2014: 269-287, DOI: 10.15294/pandecta.v9i2.3580.

Angermeyer, Philipp Sebastian. "Monolingual Ideologies and Multilingual Practices in Small Claims Court: the Case of Spanish-Speaking Arbitrators", International Journal of Multilingualism, International Journal of Multilingualism 11, no. 4, 2014: 430-448, DOI: 10.1080/14790718.2014.944531.

Astanti, Dhian Indah, et.al. "Kewenangan Pengadilan Agama Dalam Penyelesaian Sengketa Perbankan Syari'ah", Jhaper 5, no. 1, 2019: 167-180, DOI: 10.36913/jhaper.v5i1.

Crouch, Melissa. The Politics of Court Reform: Judicial Change and Legal Culture in Indonesia. United Kingdom: Cambridge University Press, 2019

Erfaniah Zuhriah, "Model SCC Sebagai Alternatif Penyelesaian Perkara di Pengadilan Agama Perspektif Teori Keadilan John Rawls", De Jure: Journal of Law and Syar'iah 11, no. 2 (2019): 128-142, 129, DOI: 10.18860/j-fsh.v11i2.6580.

Fakhriah, Efa Laela. "Mekanisme Small Claims Court Dalam Mewujudkan Tercapainya Peradilan Sederhana, Cepat, dan Biaya Ringan", Mimbar Hukum 25, no. 2, 2013: 258-270, DOI: 10.22146/jmh.16096.

Hudawati, Sinta Noer. "Problematika Hukum Formil Penyelesaian Sengketa Ekonomi Syari'ah Di Pengadilan Agama", Jurnal Penegakan Hukum dan Keadilan 1, no.1, 2020: 17-40, DOI: 10.18196/jphk.1102.

Ibrahim, Johnny. Teori dan Metodologi Penelitian Hukum Normatif, Malang: Bayumedia, 2013.

Irawan, Mul, etc. Small Claim Court Dan Pengadilan Agama Sebuah Catatan Pembuka. Jakarta: Puslitbang Hukum dan Peradilan Mahkamah Agung, 2018.

Kusmayanti, Hazar., et.al. "Praktik Penyelesaian Sengketa di Pengadilan Agama Melalui Sidang Keliling Dikaitkan dengan Prinsip dan Asas 
Hukum Acara Perdata", JHAPER 4, no. 2, 2018: 145-161, DOI: 10.36913/jhaper.v4i2.83.

Kusmayanti, Hazar., et.al. "Sidang Keliling dan Prinsip-prinsip Hukum Acara Perdata: Studi Pengamatan Sidang Keliling di Pengadilan Agama Tasikmalaya", JHAPER 1, no. 2, 2015: 101-116, DOI: 10.36913/jhaper.v1i2.14.

Roro, Fiska Silvia Raden., et.al, "The Characteristics of Sharia Compliance in the Settelment of Sharia Economic Disputes in Indonesia", Advance in Sosial Science Education and Humanities Research (ASSEHR) 131, (2017): 113-126, DOI: 10.2991/iclgg-17.2018.15.

Soekanto, Soerjono., Mamudji, Sri. Penelitian Hukum Normatif, Suatu Tinjauan Singkat. Jakarta: Radja Grafindo Persada, 2012.

Yahya Harahap, Kedudukan Kewenangan Dan Acara Peradilan Agama Berdasarkan Undang-Undang No. 7 Tahun 1989. Jakarta: Sinar Grafika, 2003.

Yaqin, Muharrom Ainul. "Konsep Small Claim Procedure Untuk Menyelesaikan Perkara Perdata Permohonan (Volunter) Di Pengadilan Agama", Jurisdictie 6, no. 1, 2015: 37-48, DOI: 10.18860/j.v6i1.4088, 